\title{
The impact of financial performance on workplace bullying and mistreatment in Serbian organizations
}

\author{
Утицај финансијских перформанси на мобинг и \\ малтретирање на радном месту у организацијама у \\ Србији
}

\author{
Sanja Stankov, PhD Student \\ University of Novi Sad, Technical Faculty “Mihajlo Pupin”, Zrenjanin, Serbia, sssanja89@gmail.com \\ Jasmina Poštin * \\ University "Union - Nikola Tesla", Beograd, "Faculty of Management", Sremski Karlovci, Serbia, \\ famzr.edu@gmail.com \\ Marko Konjikušić \\ University "Union - Nikola Tesla", Beograd, "Faculty of Management", Sremski Karlovci, Serbia, \\ markozr1979@yahoo.com \\ Aleksandra Jagodić Rusić \\ University "Business Academy", Faculty of Economics and Engineering Management, Novi Sad, Serbia, \\ aleksandra@aio.rs \\ Daliborka Mićić \\ University "Union - Nikola Tesla", Beograd, "Faculty of Management", Sremski Karlovci, Serbia, \\ micicdaliborka@gmail.com
}

\begin{abstract}
This paper presents the results of research into the impact of organizational financial performance items (and financial performance dimension) on workplace bullying and mistreatment. The research was conducted in organizations in Serbia, and the respondents were employees in these organizations. A total of 536 questionnaires were collected, which were valid for further analysis. The results showed that most of the observed financial performance items did not have a statistically significant impact on workplace bullying in organizations. However, the item Salaries; statistically significantly, strongly and negatively affects all observed workplace bullying dimensions and self-labelling (mistreatment) items. Thus, low employee salaries provide fertile ground for the development of workplace bullying. Conversely, with an increase in employee salaries, there is a decrease in all aspects of workplace bullying. The paper gives explanations for these phenomena. It is important for leaders and managers in business organizations to know the processes and relationships researched here. Special care should be taken in conditions of unfavourable organizational financial performance, and especially low salaries of employees.
\end{abstract}

Keywords: Organizational financial performances, Salaries, Workplace bullying, Mistreatment, Serbia. JEL classification: D23, J50, J70.

Сажетак: У раду су приказани резултати истраживања утицаја ајтема организационих финансијских перформанси (и димензије финансијских перформанси) на мобинг и малтретирање на радном месту. Истраживање је реализовано у организацијама у Србији, а испитаници су били запослени у овим

Corresponding author 
организацијама. Сакупљено је укупно 536 упитника, који су били валидни за даље анализе. Резултати су показали да већина посматраних ајтема финансијских перформанси нема статистички значајан утицај на мобинг у организацијама. Међутим, ајтем Плате статистички значајно, снажно и негативно утиче на све посматране димензије мобинга и ајтем малтретирање. Дакле, ниске зараде запослених представљају плодно тло за развој мобинга. Супротно томе, са повећањем плата запослених, долази до смањења свих аспеката мобинга. У раду су дата образложења за ове појаве. За лидере и менаџере у пословним организацијама је важно да познају овде истраживане процесе и релације. Посебан опрез треба да постоји у условима неповољних организационих финансијских перформанси, а нарочито ниских зарада запослених.

КЉучне речи: Организационе финансијске перформансе, плате, мобинг, малтретирање, Србија. JEЛ класификација: D23, J50, J70.

\section{Introduction}

Over two decades of international research has provided sufficient evidence of the negative effects of workplace bullying on employees and the organizations in which they work. Workplace bullying is today considered one of the most harmful stressors in modern work life (Niedhammer et al., 2013) and is defined as a global interest phenomenon (Nielsen \& Einarsen, 2018). Bullying is a long-term aggression directed at a person who is unable to defend himself/herself, which leads to the victimization of that person. The victim, who is unable to escape from the social situation and thus, his tormentor, is exposed to escalating harassment leading to loss of self-esteem and a gradual increase in mental stress (Björkqvist et al., 1994). Björkqvist, Österman and Hjelt-Bäck (1994) note that it is important to keep in mind that harassment does not start with the victim, but with the attacker, so without the attacker there would be no harassment.

Brodsky (1976) presents perspectives on psychological injuries at work, addressing the problems: Who is responsible for harassing workers? What is the statistical evidence of harassment? How can the harassment system change? Brodsky (1976) reports three sources of harassment: (1) by humans, (2) work pressure, and (3) by the system. He gives examples of his theory, describing a series of cases in which employees at all organizational levels claimed to have been harassed by superiors or colleagues, resulting in destructive effects on their productivity, health and well-being. However, this pioneering examination of harassment at Brodsky's work did not attract significant attention at that time. The first scientific paper on the concept of harassment at work, published in 1989 in Norwegian (Matthiesen et al., 1989), studied the extent and frequency of harassment in the workplace, reports of harassment, and the effects of abuse on mental and physical health and job satisfaction. The studies of the Swedish psychologist and psychiatrist, of German descent Leymann, whose major works appeared in the early 1980s, are important. His first major article on workplace bullying (Leymann, 1990a) discusses targeting the employee and subjecting the employee to psychological harassment, while one of his more important contributions was the development of one of the first questionnaires for examining workplace bullying - the Leymann Inventory of Psychological Terror (LIPT).) (Leymann, 1990b). 
Dealing with workplace bullying can be especially difficult where it is accepted as part of organizational culture. Thus, organizational culture has been identified as a possible cause of workplace bullying (Rayner et al., 2002; Hoel \& Salin, 2003). Workplace bullying has a greater potential to occur in organizations with a culture that allows or rewards such behaviour (Brodsky, 1976). In organizations where there is an established clear policy, code of ethics, clearly defined responsibilities and authorities, it will be more difficult for violence to occur. However, in any case and situation, it is important to stop the violence at the earliest stage. Abuse leads to several adverse outcomes for organizations (Hoel et al., 2003), such as: reduced organizational efficiency, which may be partly due to the increased intention to leave the organization (Djurkovic et al., 2006), and then the need for the organization to deal with complaints, investigations, disputes, as well as poor publicity (Hoel et al., 2003). However, above all, abuse primarily leads to negative influences and psychosomatic symptoms on victim (Djurkovic et al., 2004). As the effects of abuse do not stop at the victim alone, it further harms the victim's family and friends, as well as witnesses to the abuse (Hoel et al., 2002; Rayneret al., 2002). Various social factors can make the workplace prone to violence.

What is particularly important for this work is linking organizational performance and workplace bullying. Studies (Sheehan et al., 1998; McCarthy \& Barker, 2000) reveal poorer work performance of employees who have experienced workplace bullying, and this specifically includes reports of reduced productivity, efficiency, lower performance, and quality of work. Workplace bullying is associated with absenteeism followed by reduced productivity (Magee et al., 2017). Empirical evidence between workplace bullying and productivity is scarce, in part because it is difficult to measure productivity, except in selfreporting studies, where respondents observe changes in organizational performance due to abuse (Hoel et al., 2010). A moderate negative correlation was found between self-assessed performance and abuse (Hoel et al., 2001). Finally, there is no doubt that harassment at work seriously damages organizational performance. If an official procedure or a court case is initiated, the loss of time and energy is huge. If these processes reach the public eye, the image of the organization suffers great damage. This is even more important if we keep in mind that some research in Serbia (Aničić et al., 2020; Vojteski-Kljenak et al., 2019) shows that, in general, it is very important to provide efficiently manage revenues, costs, profits, assets, and financial structure in order to improve the organizational performance of companies.

The aim of this paper is to examine whether organizational financial performance has an impact on workplace bullying and mistreatment, and if so, what is the direction of that impact. In other words, the question arises: does the success of the organization and its good financial results increase the pressure on employees, competition among colleagues, and thus create conditions for more explicit workplace bullying, or does it actually happen when the success of the organization is low, so there are fears of losing jobs, salary cuts, etc.? A similar dilemma arises in the recent work (Salin \& Notelaers, 2020), where the direction of the impact of high-performance work practices (HPWPs) on workplace bullying is examined. The results showed that HPWPs reduced the risk of workplace bullying. This is a challenge for research in which HPWPs are described as a factor for 
stress and burnout (Kroon et al., 2009; Ogbonnaya \& Messersmith, 2019; Zhang et al., 2013), and also as a factor for abuse and workplace bullying (Ashkanasy et al., 2016; Lewis \& Rayner, 2003; Salin \& Hoel, 2011; Samnani \& Singh, 2014). Salin and Notelaers (2020) conclude that "a more nuanced discussion" on this topic is necessary. In that sense, this paper can be accepted as a contribution to this discussion, which is, practically, just open. The impact of certain organizational financial performance items on workplace bullying dimensions and mistreatment item was examined in organizations in Serbia. This paper presents the results of that research, as well as their discussion.

\section{Theory and hypothesis}

\subsection{The relationship of power and victim traits}

Workplace bullying can be seen as an unresolved social conflict, which has reached a high level of escalation and which involves an imbalance of power between the parties (Zapf \& Gross, 2001). Einarsen, Hoel, Zapf and Cooper (2010) talk about predator abuse, where the victim has done nothing provocative that can justify the perpetrator's behaviour, and only by coincidence finds himself in a situation where the predator abuses power, or exploits the weakness of someone who accidentally became victim. Sources of power for the perpetrator, in relation to the victim, can be: higher hierarchical position, better access to resources in the organization, belonging to a privileged group of employees and the possibility of using other people as "performers" of abuse (Tehrani, 2012).

There has been much speculation about whether personality traits that are typical of victims can be identified. According to (Björkqvist et al., 1994), anyone can become a victim, but provided that the individual has less power than the attacker. One of the reasons why the victim has fewer opportunities to defend himself or herself in the workplace is usually of a hierarchical-organizational nature, for example, when a person in a higher position harasses a subordinate or when a group of employees wants to get rid of a competitor (Leymann, 1992). While some have characterized victims as introverted, conscientious, literal, who reflect a bad self-image, and are occasionally successful (Matthiesem \& Einarsen, 2001), other authors suggest that there is no difference between victims and non-victims, and that the question of who will become victim to workplace bullying is entirely a matter of chance and unfortunate circumstances (Leymann, 1992).

It should also be kept in mind here that what one person may see as abusive behaviour does not necessarily mean that the other person would experience the same (Coyne et al., 2004). Thus, Painter (1991) states that any assessment of abusive behaviour should take into account the subjective assessment factor. 


\subsection{Some of the consequences of workplace bullying}

The intention to leave the organization. Among the potential organizational outcomes of workplace harassment, turnover was particularly interesting for researchers. Numerous studies have shown a positive relationship between harassment in the workplace, intention to leave the organization and turnover (Quine 1999; Hoel \& Cooper, 2000; Djurkovic et al., 2004). A study in Ireland (O'Connell et al., 2007) has shown that $60 \%$ of respondents exposed to workplace bullying considered leaving the organization, while $15 \%$ actually did so. Although "the intention to leave an organization" is considered a key predictor of turnover (Begley, 1998), Hoel, Sheehan, Cooper and Einarsen (2010) note that, with a few exceptions, most studies focus on research of "the intention to leave an organization", and not on the actual turnover or giving up the work. A longitudinal study, conducted in Norway (Berthelsen, Skogstad, Hauge, Nielsen, Einarsen, 2009), has shown that although some victims of abuse actually left the organization two years after they first reported experiencing abuse, most victims were still at the same job, even after two years. The strong connection between workplace bullying and the intention to leave the organization can be seen from the angle of coping strategy, which can be positive for victims because it completely removes them from the source of the problem, which is in accordance with the advice that victims often give to other victims (Zapf \& Gross, 2001).

Health issues. However, negative influences in the workplace are primarily manifested through negative emotions, such as anger, nervousness, worry, anxiety, guilt (Watson \& Clark, 1984). Workplace bullying has been shown to cause a variety of psychological and physical symptoms (Hoel et al., 2004; Fox \& Stallworth, 2005). Psychological symptoms include stress, anxiety, depression, and difficulty concentrating (Vartia, 2001; Mikkelsen \& Einarsen, 2002), while physical symptoms include sleep disturbance, stomach upset, headaches, body aches, exhaustion, and rapid heartbeat (O'Moore et al., 1998; Vartia, 2001). Workplace bullying is a causative factor for many mental health problems and can make victims susceptible to serious physical conditions, such as cardiovascular disease (Kivimaki et al., 2003).

Those who experience violence may feel anxious, intimidated and humiliated. Violence can cause feelings of frustration and anger and lead to stress, loss of selfconfidence and self-esteem. There is strong evidence that negative psychological states cause the disease, for example: stress is contributing to the development of the disease because it disturbs the balance of the body, and anxiety can eventually lead to stomach disorders (Đurkovic et al., 2006). Violence also reflects on business motivation, work performance and the level of absence from work. Other symptoms may include headache, high blood pressure and insomnia. In addition to the costs associated with abuse, it can cost employers in other ways as it can affect the culture of the entire organization, which ultimately can have a very bad impact on the reputation of the organization.

This paper raises two hypotheses and one research question:

H1: There is a statistically significant correlations between the financial performance items (and financial performance dimension) and the workplace bullying dimensions and self- 
labelling (mistreatment) item.

$\mathrm{H} 2$ : There is a statistically significant predictive effect of the financial performance items (and financial performance dimension) on the workplace bullying dimensions and selflabelling (mistreatment) item.

RQ: What is the direction of the impact of financial performance items (and financial performance dimension) on the workplace bullying dimensions and self-labelling (mistreatment) item?

\section{Methods}

\subsection{Survey instruments (measures)}

Workplace bullying. Workplace bullying was measured by the Negative Acts Questionnaire-Revised instrument, NAQ-R (Einarsen et al., 2009), which was validated into Serbian in the reference (Vukelić et al., 2015). The questionnaire consists of 22 items (3 dimensions: Work related bullying, Person related bullying and Physically intimidating bullying). In addition, the workplace bullying dimension (NAQ-R total) was used in the analysis, and it includes all of 22 items. Respondents answered how often they were exposed to each item in the last six months, offering five categories of responses: "never", "occasionally", "monthly", "weekly" and "daily".

Self-labelled victim of bullying (mistreatment item). Self-labelling (mistreatment) was measured by one item, based on a reference by Einarsen, Hoel, Notelaers (2009). Respondents answered the question whether and to what extent they were harassed at work during the last six months (before that, the definition of harassment was given). Five categories of answers were offered: "no", "yes, occasionally", "yes, several times a month", "yes, several times a week" and "yes, almost every day".

Financial performance. In order to measure financial performance, a questionnaire of 7 items was compiled: Productivity, Profitability, Market Share, Sales Growth, Competitive Status, Asset Growth and Employee Salaries. References were used in the selection of these items (Tan \& Litschert, 1994; Wang et al., 2003; Wang et al., 2011). All financial performance items were measured using a seven-point Likert scale. Also, all seven items make up one dimension: Financial performance.

\subsection{Participants and data collection}

The research was carried out in Serbian organizations. The research was realized in such a way that respondents were completing questionnaires. Respondents were employed in organizations in Serbia, at various organizational levels. A total of 536 questionnaires were collected, which was valid for further analysis. 


\section{Results}

\subsection{Descriptive statistics}

Table 1 shows the results of descriptive statistics (workplace bullying dimensions, selflabelling item, financial performance items and financial performance dimension). The table gives the names for dimensions and items, short name for each dimension and item, mean values and standard deviation of all dimensions and items, as well as Cronbach's alpha for each dimension. Cronbach's alpha values range from 0.755 to 0.964 .

Table 1: Descriptive statistics

\begin{tabular}{|l|c|c|c|c|c|c|c|}
\hline Dimensions and items & Short name & $\mathrm{N}$ & Min & Max & Mean & $\begin{array}{c}\text { Std. } \\
\text { Deviation }\end{array}$ & $\begin{array}{c}\text { Cronbach's } \\
\text { alpha }\end{array}$ \\
\hline Work related bullying & WRB & 536 & 1.00 & 5.00 & 2.15 & .969 & 0.903 \\
\hline Person related bullying & PRB & 536 & 1.00 & 5.00 & 1.86 & .865 & 0.948 \\
\hline Physically intimid. bull. & PIB & 536 & 1.00 & 5.00 & 1.55 & .714 & 0.755 \\
\hline Workplace bullying & WB & 536 & 1.00 & 5.00 & 1.91 & .831 & 0.964 \\
\hline Self-labelling (mistreatm.) & SLM & 536 & 1.00 & 5.00 & 1.88 & 1.060 & - \\
\hline Productivity & FP1 & 536 & 1 & 7 & 4.90 & 1.595 & - \\
\hline Profitability & FP2 & 536 & 1 & 7 & 4.84 & 1.698 & - \\
\hline Market share & FP3 & 536 & 1 & 7 & 4.64 & 1.770 & - \\
\hline Sales growth & FP4 & 536 & 1 & 7 & 4.49 & 1.817 & - \\
\hline Competitive status & FP5 & 536 & 1 & 7 & 4.60 & 1.781 & - \\
\hline Asset growth & FP6 & 536 & 1 & 7 & 4.16 & 1.618 & - \\
\hline Salaries & FP7 & 536 & 1 & 7 & 3.95 & 1.577 & - \\
\hline Financial performance & FP & 536 & 1.00 & 7.00 & 4.51 & 1.416 & 0.927 \\
\hline & Valid N & 536 & & & & & \\
\hline
\end{tabular}

Source: Authors

\subsection{Correlation analysis}

The results of the correlation analysis between financial performance items (and financial performance dimension) and workplace bullying dimensions and self-labelling (mistreatment) item, are given in Table 2. The results refer to the total sample $\mathrm{N}=536$ respondents. Pearson's correlation was used. In Table 2, statistically significant correlations were marked: ${ }^{*} \mathrm{p}<0.05 ; * * \mathrm{p}<0.01$.

Table 2: Coefficients of correlation between the financial performance items (and financial performance dimension) and the workplace bullying dimensions and self-labelling (mistreatment) item

\begin{tabular}{|c|c|c|c|c|c|}
\hline & WRB & PRB & PIB & WB & SLM \\
\hline FP1 &,- 077 &,- 074 &,$- 100^{*}$ &,- 082 &,- 033 \\
\hline FP2 &,- 044 &,- 039 &,- 051 &,- 044 &, 004 \\
\hline FP3 &,- 022 &,- 007 &,- 054 &,- 019 &, 000 \\
\hline FP4 &,- 004 &, 002 &,- 009 &,- 001 &, 038 \\
\hline FP5 &,- 004 &,- 019 &,- 052 &,- 018 &,- 022 \\
\hline
\end{tabular}




\begin{tabular}{|c|c|c|c|c|c|}
\hline FP6 &,- 057 &,- 043 &,- 021 &,- 048 &,- 004 \\
\hline FP7 &,$- 279^{* *}$ &,$- 272^{* *}$ &,$- 228^{* *}$ &,$- 285^{* *}$ &,$- 260^{* *}$ \\
\hline FP &,- 079 &,- 073 &,$- 085^{*}$ &,- 081 &,- 044 \\
\hline
\end{tabular}

Source: Authors

\subsection{Regression analysis}

The predictive effect of the financial performance items (independent variables) on the workplace bullying dimensions and self-labelling (mistreatment) item (dependent variables) was examined using Multiple Regression analysis (Table 3). Dimension FP - Financial performance is not taken into account here due to the possibility that, as an overall dimension, it takes on a significant part of the predictive effect. The results in Table 3, for which there is a statistically significant predictive effect, are marked by a bold font.

Table 3: Regression analysis (independent variables: financial performance items; dependent variables: workplace bullying dimensions and mistreatment item)

\begin{tabular}{|c|c|c|c|c|c|c|c|c|c|c|}
\hline & \multicolumn{7}{|c|}{ Indep. } & FP7 \\
\hline Depend. & FP1 & FP2 & FP3 & FP4 & FP5 & FP6 & FP7 & R $^{2}$ & F & Sig. \\
\hline & & & & $\beta$ & & & & & & \\
\hline WRB & $-0,068$ & 0,021 & 0,024 & 0,114 & 0,060 & 0,016 & $\mathbf{- 0 , 3 4 7}$ & $\mathbf{0 , 0 9 9}$ & 8,317 & 0,000 \\
\hline PRB & $-0,080$ & 0,017 & 0,069 & 0,112 & 0,005 & 0,044 & $\mathbf{- 0 , 3 4 5}$ & $\mathbf{0 , 0 9 7}$ & 8,086 & 0,000 \\
\hline PIB & $-0,133$ & 0,055 & $-0,046$ & 0,152 & $-0,043$ & 0,118 & $\mathbf{- 0 , 2 7 8}$ & $\mathbf{0 , 0 7 5}$ & 6,095 & 0,000 \\
\hline WB & $-0,086$ & 0,024 & 0,042 & 0,124 & 0,020 & 0,044 & $\mathbf{- 0 , 3 5 7}$ & $\mathbf{0 , 1 0 4}$ & 8,786 & 0,000 \\
\hline SLM & $-0,031$ & 0,062 & $-0,018$ & 0,161 & $-0,057$ & 0,094 & $-\mathbf{0 , 3 6 3}$ & $\mathbf{0 , 1 0 2}$ & 8,613 & 0,000 \\
\hline
\end{tabular}

Source: Authors

\section{Discussion}

\subsection{Discussion of the results of correlation analysis}

Based on the results from Table 2, it is easy to see that only the item FP7 - Salaries does have statistically significant effects on workplace bullying dimensions and self-labelling (mistreatment) item. However, these impacts are negative. This means that low employee income provides fertile ground for the development of workplace bullying. Low employee income is an indicator of poor business operations of the organization, and this often means reduced workload and absence of important jobs, but also reduced job satisfaction. All this contributes to the employees having excess time and lack of satisfaction, which leads to a redirection of attention to the political processes in the organization. In such conditions, it is easy to create an atmosphere in which individuals are unjustifiably favoured and, at all costs, the company is looking for the culprits for the bad situation. Threats and blackmails are possible in terms of fear for keeping a job, earning a salary, so some employees begin to feel threatened and scared for their job, salary, etc. 
Conversely, with an increase in employee's income, there is a decrease in all aspects of workplace bullying. Relatively high salaries create a strong perception of justice, motivate people to work harder and better, they then have neither the time nor the need to deal with (re)distribution of power in the organization, blackmail and, in general, to deal with subordinates or superiors in a way that is not related to doing the job. Most employees are focused on their job. A well-paid and satisfied worker finds it much harder to end up in a situation where he or she suffers from workplace bullying, and if that happens, he or she will have more self-confidence and organizational tools to resist such occurrence.

Another statistically significant and negative correlation between item FP1 Productivity, and dimension PIB - Physically Intimidating Bullying should be noted. In other words, high productivity can reduce physical intimidation. This phenomenon can be explained by the fact that in conditions of high productivity, employees simply have an increased volume of work and do not have time to deal with physical intimidation. In addition, high productivity is a sign of the efficiency of people in lower positions, and in such circumstances, superiors have no need (or justification) to be angry at subordinates, shout at subordinates, physically threaten them, etc. Due to this result, there is a statistically significant (negative) impact of dimension FP - Financial performance on dimension PIB Physically Intimidating Bullying.

Other correlations in Table 2 are not statistically significant. Based on the previous considerations, it can be stated that hypothesis $\mathrm{H} 1$ is partially confirmed, more precisely, it is confirmed in the influences of items FP7 - Salaries and FP1 - Productivity on workplace bullying dimensions as well as self-labelling (mistreatment) item. At the same time, this is the answer to the research question RQ: where there are statistically significant effects of financial performance items (and financial performance dimension) on the workplace bullying dimensions and self-labelling (mistreatment) item, these effects are negative. This puts this research on the side of the study (Salin, Notelaers, 2020), which shows that high work performance reduces workplace bullying.

According to the results from Table 3, of the financial performance items, only item FP7 - Salaries has statistically significant predictive effects on workplace bullying dimensions. These effects are negative in all cases, so this result is fully consistent with the results of the correlation analysis. The explanations for this phenomenon, which are given in the discussion of the results of correlation analysis, are also valid in the results of regression analysis.

The corrected determination indexes R2 have slightly lower values (ranging from 0.075 to 0.104 ), but all these values are statistically significant (Table 3 ). Based on these findings, hypothesis $\mathrm{H} 2$ can be considered confirmed. Although the values of R2 are quite close, it can be said that the strongest predictive effect occurs on the dimension WB Workplace bullying and item SLM - Self-labelling (mistreatment), and the weakest on the dimension PIB - Physically Intimidating Bullying. This is a consequence of the fact that the dimension WB - Workplace bullying and item SLM - Self-labelling (mistreatment) have a more general character, so they attract different influences. On the other hand, the 
dimension PIB - Physically Intimidating Bullying is still represented to a much lesser extent, it refers to some very extreme situations, which (fortunately) do not seem to be common (average score for dimension PIB - Physically Intimidating Bullying is only 1.55 (Table 1 Descriptive statistics).

\subsection{Limitations}

The limitation of this research is that it was conducted in companies in Serbia, so the results, in the first place, are valid for the observed subject of research. At the same time, the results are logical, so based on the given discussions, we can rightly assume the general character of the obtained results, i.e. that the results are applicable in different conditions, and thus in different countries.

\section{Conclusion}

Organizational financial performance items, in general, do not have a large impact on the occurrence of workplace bullying in organizations. However, one financial performance item stands out from this group. This is item FP7 - Salaries, which statistically both significantly and negatively affects all observed workplace bullying dimensions and selflabelling (mistreatment) item. This was confirmed by both the results of the correlation analysis and the results of the regression analysis. In a situation where the salaries of employees are low, dissatisfaction with work and excess time for employees are present. This can be further linked to various forms of political processes in the organization, the phenomena of unfair rewarding and punishment, promotion and restraint, as well as the phenomena of threats, blackmail, intimidation and, finally, workplace bullying. In this way, the answer to the research question is given, as well as the dilemma from the beginning of work: low performance of the organization, poor financial performance, and especially low salaries of employees, are what leads to increased workplace bullying.

It is important for leaders and managers in business organizations to know the processes and phenomena researched here. In that way, they qualify themselves for successful recognition and understanding of potential and real workplace bullying situations, and afterwards for their efficient and effective overcoming. Special care should be taken in conditions of unfavourable organizational financial performance, especially low income of employees.

\section{References}

Aničić, D., Aničić, J., Miletić, V. (2020). Cost management efficiency factors of enterprises in Serbia. Ekonomika, 66(1), 37-51. Doi: https://doi.org/10.5937/ekonomika2001037A

Ashkanasy, N., Bennett, R., Martinko, M. (2016). Understanding the high performance workplace: The line between motivation and abuse. New York: Routledge.

Begley, T.M. (1998). Coping strategies as predictors of employee distress and turnover after an organizational consolidation: A longitudinal analysis. Journal of Occupational and 
Organizational Psychology, 71(4), 305-329. Doi: https://doi.org/10.1111/j.2044$\underline{\text { 8325.1998.tb00679.x }}$

Berthelsen, M., Skogstad, A., Hauge, L.J., Nielsen, M.B., Einarsen, S. (2009). Mobbing og ustøtning fra arbeidslivet (Bullying and exclusion from working life). Bergen, Norway: University of Bergen.

Björkqvist, K., Österman, K., Hjelt-Bäck, M. (1994). Aggression among university employees. Aggressive Behavior, 20(3), 173-184. Doi: https://doi.org/10.1002/10982337(1994)20:3\%3C173::AID-AB2480200304\%3E3.0.CO;2-D

Brodsky, C.M. (1976). The Harassed Worker. Toronto: Lexington Books, DC Heath and Company.

Coyne, I., Craig, J., Smith-Lee Chong, P. (2004). Workplace bullying in a group context. British Journal of Guidance and Counseling, 32(3), 301-316. Doi: https://doi.org/10.1080/03069880410001723530

Djurkovic, N., McCormack, D., Casimir, G. (2004). The physical and psychological effects of workplace bullying on intention to leave: A test of the psychosomatic and disability hypotheses. International Journal of Organization Theory and Behavior, 7(4), 469-497. Doi: https://doi.org/10.1108/IJOTB-07-04-2004-B001

Djurkovic, N., McCormack, D., Casimir, G. (2006). Neuroticism and the psychosomatic model of workplace bullying. Journal of Managerial Psychology, 21(1), 73-88. Doi: https://doi.org/10.1108/02683940610643224

Einarsen, S., Hoel, H., Notelaers, G. (2009). Measuring exposure to bullying and harassment at work: Validity, factor structure and psychometric properties of the negative acts questionnaire-revised. Work and Stress, 23(1), 24-44. Doi: https://doi.org/10.1080/02678370902815673

Einarsen, S., Hoel, H., Zapf, D., Cooper, C. (2010). The concept of bullying and harassment at work. In book: Bullying and Harassment in the Workplace, 3-39.

Fox, S., Stallworth, L. (2005). Racial/ethnic bullying: exploring links between bullying and racism in the US workplace. Journal of Vocational Behavior, 66(3), 438-456. Doi: https://doi.org/10.1016/j.jvb.2004.01.002

Hoel, H., Cooper, C.L. (2000). Destructive conflict and bullying at work. Sponsored by the British Occupational Health Research Foundation (BOHRF), Manchester School of Management, Manchester University of Science and Technology (UMIST).

Hoel, H., Sparks, K., Cooper, C.L. (2001). The cost of violence/stress at work and the benefits of a violence/stress-free working environment. Geneva: International Labour Organisation. 
Hoel, H., Zapf, D., Cooper, C.L. (2002). Workplace bullying and stress. Research in Occupational Stress and Well-being, 2, 293-333. Doi: https://doi.org/10.1016/S1479$\underline{3555(02) 02008-5}$

Hoel, H., Salin, D. (2003). Organisational antecedents of workplace bullying. In S. Einarsen, H. Hoel, D. Zapf, \& C.L. Cooper (Eds.), Bullying and Emotional Abuse in The Workplace: International Perspectives in Research and Practice, (pp. 203-218). London: Taylor \& Francis,

Hoel, H., Einarsen, S., Cooper, C.L. (2003). Organisational effects of bullying. In S. Einarsen, H. Hoel, D. Zapf, \& C.L. Cooper (Eds.), Bullying and emotional abuse in the workplace: International perspectives in research and practice, (pp. 145-161). London: Taylor \& Francis.

Hoel, H., Faragher, B., Cooper, C.L. (2004). Bullying is detrimental to health, butall bullying behaviors are not necessarily equally damaging. British Journal of Guidance and Counselling, 32(3), 367-387. Doi: https://doi.org/10.1080/03069880410001723594

Hoel, H., Sheehan, M., Cooper, C., Einarsen, S. (2010). Organisational effects of workplace bullying. In: Einarsen S, Hoel H, Zapf D, Cooper CL, (eds.). Bullying and harassment in the workplace. Developments in theory, research, and practice, (pp. 129-148). Lonond: CRC Press.

Kivimaki, M., Virtanen, M., Vartia, M., Elovainio, M., Vahtera, J., Keltikangas-Jarvinen, L. (2003). Workplace bullying and the risk of cardiovascular disease and depression. Occupational and Environmental Medicine, 60(10), 779-783. Doi: http://dx.doi.org/10.1136/oem.60.10.779

Kroon, B., van de Voorde, K., van Veldhoven, M. (2009). Cross-level effects of highperformance work practices on burnout: Two counteracting mediating mechanisms compared. Personnel Review, 38(5), 509-525. Doi: https://doi.org/10.1108/00483480910978027

Lewis, D., Rayner, C. (2003). Bullying and human resource management: A wolf in sheep's clothing? In S. Einarsen, H. Hoel, D. Zapf, \& C.L. Cooper (Eds.), Bullying and emotional abuse in the workplace: International perspectives in research and practice. (pp. 370-382). London: Taylor \& Francis.

Leymann, H. (1992). Från mobbning till utslagning $i$ arbetslivet (From mobbing to exclusion in the workplace). Stockholm. Sweden: Publica.

Leymann, H. (1990a). Mobbing and psychological terror at workplaces. Violence and Victims, 5(2), 119-126. Doi: https://doi.org/10.1891/0886-6708.5.2.119

Leymann, H. (1990b). Handbok för användning av LIPT-formuläret för kartläggning av risker för psykologisk vald (Manual of the LIPT questionnaire for assessing the risk of psychological violence at work). Violen, Stockholm. 
Magee, C, Gordon, R, Robinson, L, Caputi, P, Oades, L. (2017). Workplace bullying and absenteeism: The mediating roles of poor health and work engagement. Human Resource Management Journal, 27(3), 319-334. Doi: https://doi.org/10.1111/1748-8583.12156

Matthiesem, S.B., Einarsen, S. (2001). MMPI-2 configurations among victims of bullying at work. European Journal of Work and Organizational Psychology,10(4), 467-484. Doi: https://doi.org/10.1080/13594320143000753

Matthiesen, S.B., Raknes, B.I., Røkkum, O. (1989) Mobbing på arbeidsplassen (Workplace bullying). Tidsskrift for Norsk Psykologforening, 26(11), 761-774.

McCarthy, P., Barker, M. (2000). Workplace bullying risk audit. Journal of Occupational Health and Safety, Australia and New Zealand, 16(5), 409-418.

Mikkelsen, E., Einarsen, S. (2002). Relationships between exposure to bullying at work and psychological and psychosomatic health complaints: the role of state negative affect and generalized self-efficacy. Scandinavian Journal of Psychology, 43(5), 397-405. Doi: https://doi.org/10.1111/1467-9450.00307

Niedhammer, I., Chastang, J.F., Sultan-Taieb, H., Vermeylen, G., Parent-Thirion, A. (2013). Psychosocial work factors and sickness absence in 31 countries in Europe. European Journal of Public Health, 23(4), 622-629. Doi: https://doi.org/10.1093/eurpub/cks124

Nielsen, M.B., Einarsen, S.V. (2018). What we know, what we do not know, and what we should and could have known about workplace bullying: An overview of the literature and agenda for future research. Aggression and Violent Behavior, 42, 71-83. Doi: https://doi.org/10.1016/j.avb.2018.06.007

O'Connel, P.J., Calvert, E., Watson, D. (2007). Bullying in the workplace: Survey report Department of Enterprise Trade and Employment. The Economic and Social Research Institute, Ireland.

Ogbonnaya, C., Messersmith, J. (2019). Employee performance, well-being, and differential effects of human resource management subdimensions: Mutual gains or conflicting outcomes? Human Resource Management Journal, 29(3), 509-526. Doi: https://doi.org/10.1111/1748-8583.12203

O’Moore, M., Seigne, E., McGuire, L., Smith, M. (1998). Victims of workplace bullying in Ireland. The Irish Journal of Psychology, 19(2-3), 345-357. Doi: https://doi.org/10.1080/03033910.1998.10558195

Painter, K. (1991). Wife rape, marriage and the law: Survey report: Key findings and recommendations. Manchester: Faculty and Economic and Social Studies, University of Manchester.

Quine, L. (1999). Workplace bullying in NHS community trust: Staff questionnaire survey. British Medical Journal, 318(7178), 228-232. Doi: https://doi.org/10.1136/bmj.318.7178.228 
Rayner, C., Hoel, H., Cooper, C. L. (2002). Workplace Bullying: What We Know, Who Is to Blame, and What Can We Do? London: Taylor \& Francis.

Salin, D., Hoel, H. (2011). Organizational causes of bullying. In S. Einarsen, H. Hoel, D. Zapf, \& C.L. Cooper (Eds.), Workplace bullying and harassment: Developments in theory, research and practice. (2nd ed., pp. 227-243). London: Taylor \& Francis.

Salin, D, Notelaers, G. (2020). Friend or foe? The impact of high performance work practices on workplace bullying. Human Resource Management Journal, 30(2), 312-326. Doi: https://doi.org/10.1111/1748-8583.12281

Samnani, A-K., Singh, P. (2014). Performance-enhancing compensation practices and employee productivity: The role of workplace bullying. Human Resource Management Review, 24(1), 5-16. Doi: https://doi.org/10.1016/j.hrmr.2013.08.013

Sheehan, M., McCarthy, P., Kearns, D. (1998). Managerial Styles during Organisational Restructuring: Issues for Health and Safety Practitioners. Journal of Occupational Health and Safety - Australia and New Zealand, 14(1), 31-37.

Tan, J.J., Litschert, R.J. (1994). Environment-strategy relationship and its performance implications: An empirical study of the Chinese electronics industry. Strategic Management Journal, 15(1), 1-20. Doi: https://doi.org/10.1002/smj.4250150102

Tehrani, N. (2012). Introduction to workplace bullying. In N. Tehrani (Ed.). Workplace Bullying: Symptoms and Solutions, (pp. 1-17). London: Routledge.

Vartia, M. (2001). Consequences of workplace bullying with respect to the well-being of its targets and the observers of bullying. Scandinavian Journal of Work, Environment and Health, 27(1), 63-69.

Vojteski-Kljenak, D., Lukić, R., Gavrić, G., Gavrilović, M. (2019). The operative profit margin and interest cost in retail food. Ekonomika poljoprivrede, 66(3), 799-810. Doi: https://doi.org/10.5937/ekoPolj1903799V

Vukelić, M.B. (2015). Understanding of workplace bullying through analysis of perception of negative acts (Doctoral Dissertation). University of Belgrade. Faculty of Philosophy, Serbia.

Wang, D., Tsui, A.S., Zhang, Y., Ma, L. (2003). Employment relationships and firm performance: evidence from an emerging economy. Journal of Organizational Behavior, 24(5), 511-535. Doi: https://doi.org/10.1002/job.213

Wang, H., Tsui, A.S., Xin, K.R. (2011). CEO leadership behaviors, organizational performance, and employees' attitudes. The Leadership Quarterly, 22(1), 92-105. Doi: https://doi.org/10.1016/j.leaqua.2010.12.009

Watson, D., Clark, L. (1984). Negative Affectivity: The Disposition to Experience Aversive Emotional States. Psychological Bulletin, 96(3), 465-490. Doi: https://psycnet.apa.org/doi/10.1037/0033-2909.96.3.465 
Zapf, D., Gross, C. (2001). Conflict escalation and coping with workplace bullying: A replication and extension. European Journal of Work and Organizational Psychology, 10(4), 497-522. Doi: https://doi.org/10.1080/13594320143000834

Zhang, M., Zhu, C.J., Dowling, P.J., Bartram, T. (2013). Exploring the effects of highperformance work systems (HPWS) on the work-related well-being of Chinese hospital employees. International Journal of Human Resource Management, 24(16), 3196-3212. Doi: https://doi.org/10.1080/09585192.2013.775026 